\title{
Development of a dehydrated product with edible film characteristics from mammee apple (Mammea americana L.) using Refractance Window drying
}

\author{
Cintieley dos Santos NASCIMENTO ${ }^{1}$, Antonio Manoel da Cruz RODRIGUES ${ }^{1}$, Luiza Helena Meller da SILVA ${ }^{1 *}$
}

\begin{abstract}
The Mammee apple (Mammea americana L.) is a widely grown fruit, popular in tropical areas, which is mainly consumed fresh. Refractance Window (RW) drying is used to produce food films, flakes, and powders, and may be an alternative to commercially used dry food production methods. The aim of this study was to obtain a dehydrated product from the pulp of mammee apple using RW. The dehydrated product presented a homogeneous microstructure and good mechanical $(\mathrm{TS}=1.15 \mathrm{Mpa}, \% \mathrm{E}=13.93)$ and technological properties (hygroscopicity $=21.46 \mathrm{~g} .100 \mathrm{~g}^{-1}$, water solubility index $=32.73 \pm 0.67 \mathrm{~g} .100 \mathrm{~g}$ ). RW drying was found to be a viable and low-cost method for edible film production, generating products with adequate technological characteristics and high nutritional value. Its dehydrated products can be consumed directly or used as ingredients in the development of food products.
\end{abstract}

Keywords: Mammea americana L.; film; refractance window; biocompounds; technological properties.

Practical Application: The results of this study indicate that mammee apple (Mammea americana L.) dehydrated using RW presents characteristics compatible with currently marketed edible films and higher nutritional value since they are produced only from fruit pulp, without need of any additives.

\section{Introduction}

Brazil is characterized by having different climates and ecosystems, ranging from humid tropical, through semi-arid to temperate climates. This allows for the production of a wide variety of fruits rich in bioactive compounds, such as carotenoids and phenolic compounds (Canuto et al., 2010). Northern Brazil presents a great variety of fruit species, both native and exotic, with excellent nutritional and commercial characteristics. Some of these species have gained a prominent position in tropical fruit production, both for fresh consumption and elaboration of processed food products, both in the foreign and national market (Karam et al., 2016; Biazotto et al., 2019).

Mammee apple (Mammea americana L.) (Brazilian names: abricó, abricó-do-pará, castanha-de-macaco, abricó-de-macaco, cuia-de-macaco; Spanish: "Mamey", "mameydominicano"; English: "mammee" and "mammee-apple"; French: "abricot de Saint Domingue") belongs to family Clusiaceae (Guttiferae). Because it is a wild fruit, there is little data available regarding its production and marketing. It is a perishable fruit, with high moisture content (80\%), which therefore deteriorates quickly (Braga et al., 2010; Rodrigues et al., 2016).

The choice of an adequate preservation method may be the key to its success, both regarding the preservation of compounds present in the food matrices and for obtaining higher food durability through water reduction. Refractance Window (RW) drying has been gaining prominence and can be used to dry fruit suspensions, pastes, and pulps, generating films, flakes, or powders with good sensory and nutritional properties as final products (Ochoa-Martínez et al., 2012). RW drying was shown to be a good alternative to traditional methods, since it generates dehydrated products of superior quality with lower processing costs, and therefore with higher added value (Putranto et al., 2010; Zotarelli et al., 2015; Minjares-Fuentes et al., 2017; Quinteros et al., 2018; Oliveira et al., 2019).

Several fruits and vegetables have been successfully dried using $R W$ : strawberry and carrot (Abonyi et al., 2002), pumpkin (Nindo et al., 2003a), asparagus (Nindo et al., 2003b), mango (Ochoa-Martínez et al., 2012), açai (Pavan et al., 2012), tomato (Castoldi et al., 2015), blueberry and raspberry (Nindo et al., 2004), avocado (Nindo \& Tang, 2007), protein isolates from chickpea (Tontul et al., 2018), and aloe vera (Link et al., 2017).

The aim of the present study was to apply RW to mammee apple pulp (Mammea americana $L_{\text {. }}$ ) to obtain a dehydrated product of high technological and nutritional quality for use in the food industry.

\section{Materials and methods}

\subsection{Obtaining the raw material}

Mammee apple (Mammea americana L.) fruits were purchased at the Ver-o-Peso Market (Belém/PA, Brazil) and transported to the Laboratory of Physical Measurements (LAMEFI) at the Federal University of Pará (UFPA) in Belém, Brazil. The fruits were washed with running water to remove dirt, sterilized with $100 \mathrm{ppm}$ sodium hypochlorite for $10 \mathrm{~min}$, and peeled. The pulp 
was divided into pieces, and placed into polyethylene bags, which were vacuum sealed, and stored in a freezer at $-18 \pm 2{ }^{\circ} \mathrm{C}$ until the analysis. All analyses were carried out in triplicate.

\subsection{Mammee apple pulp characterization}

Mammee apple pulp was characterized in natura for its centesimal composition. The methods recommended by the Association of Official Analytical Chemists (1997) were adopted to determine the moisture ( $\left.\mathrm{n}^{\circ} .925 .10\right)$, and ash $\left(\mathrm{n}^{\circ}\right.$. 923.03), lipid ( $\left.\mathrm{n}^{\circ} .926 .06\right)$, and total protein ( $\left.\mathrm{n}^{\circ} .920 .87\right)$ content (with a conversion factor of nitrogen into protein of 6.25). Carbohydrates were determined according to Brasil (2003), total and reducing sugars were quantified according to the Lane \& Eynon (1984), pH ( $\left.\mathrm{n}^{\circ} .981 .12\right)$, soluble solids ( $\left.\mathrm{n}^{\circ} .932 .12\right)$, and acidity ( $\left.\mathrm{n}^{\circ} .942 .15\right)$, method by the Association of Official Analytical Chemists (1997). Water activity was determined through direct reading using an AquaLab 3TE Series (Decagon, Pullman, WA, USA) with internal temperature control set to $25^{\circ} \mathrm{C} \pm 0.1$.

Total carotenoids, antioxidant activity, and color were determined for both the fresh pulp and the dehydrated product. Technological, mechanical, and morphological properties were determined only for the dehydrated product.

\section{Total carotenoid content and antioxidant activity}

Total carotenoid content was determined according to the method described by Rodrigues-Amaya (2001). Measurements were conducted using a spectrophotometer (NOVA instruments, NI 2000UV, Brazil), at wavelenghts between 20-500 nm, using petroleum ether as the blank. Antioxidant activity was quantified based on the ABTS radical method as described by Rufino et al. (2007).

\section{Color analysis}

Color analysis was performed using a colorimeter CR-400 Chroma Meter (KONICA MINOLTA, Japan) with $2^{\circ}$ observer angle and D65 illuminant operating in the CIE $\left(L^{*}, a^{*}, b^{*}\right)$ system, in which $L^{*}$ represents luminosity $\left(L^{*}=0\right.$ black and $L^{*}=100$ white), $a^{*}$ defines the transition from green $\left(-\mathrm{a}^{*}\right)$ to red $\left(+\mathrm{a}^{*}\right)$, and $\mathrm{b}^{*}$ represents the transition from blue $\left(-b^{*}\right)$ to yellow $\left(+b^{*}\right)$. The chroma index $\left(C^{*}\right)$ and hue angle $\left(h^{*}\right)$ were determined by the equipment during the measurements (Hunterlab, 2008).

\subsection{Paste preparation}

A paste was prepared by adding water to the mammee apple pulp, to achieve a more homogeneous distribution of the product on the drying equipment. To guarantee reproducibility of the solid concentration in all assays, a 2:1 pulp:water ratio $(\mathrm{w} / \mathrm{w})$ and a fixed ${ }^{\circ} \mathrm{Brix}$ value of 8.5 were adopted. Pastes were prepared by weighing the set amounts of pulp and water using an analytical scale (Shimadzu, AY220, Brazil), followed by homogenization using an LQ Diamante Black blender (Britania, Curitiba, PR, Brazil) for $1 \mathrm{~min}$. A total $500 \mathrm{~g}$ of paste was used in each drying assay.

\subsection{Refractance Window apparatus and drying process}

Drying was performed according to Costa et al. (2019), using similar equipment. The pastes were spread on the equipment over an area of $50 \times 75 \mathrm{~cm}$, forming a 3-mm-thick layer, and dehydrated at $70 \pm 2{ }^{\circ} \mathrm{C}$.

After drying, the dehydrated products were stored in polyethylene packages, vacuum-sealed, and stored at ambient temperature $\left(25 \pm 2^{\circ} \mathrm{C}\right)$ until analyzed.

\section{Technological properties}

Water Solubility Index (WSI) and Water Absorption Index (WAI): WSI and WAI were determined according to the methodology described by Anderson et al. (1969), with modifications. $1 \mathrm{~g}$ sample of the dehydrated product was weighed in previously tared centrifuge tubes. Next, $10 \mathrm{~mL}$ distilled water at $25^{\circ} \mathrm{C}$ was added to the tubes, which were stirred in a QL-901 Vortex (BIOMIXER, São Carlos, SP, Brazil) shaker to completely homogenize the samples. The tubes were then centrifuged (Thermo Electron Led GMBH, Multifuge X1R, Belo Horizonte, MG, Brazil) for $15 \mathrm{~min}$ at $1,046.45 \mathrm{~g}$. The supernatant liquids were placed in previously tared porcelain crucibles and dried in an air circulating oven for $4 \mathrm{~h}$ at $105^{\circ} \mathrm{C}$. The crucibles were weighed and the WSI was found from the ratio between the weight of the evaporated residue $(\mathrm{g})$ and the sample's dry weight (g). After the supernatant liquid was removed, the centrifuge tubes were weighed and the WAI was calculated from the ratio of the centrifuged residue ( $\mathrm{g}$ ) (gel. $\mathrm{g}^{-1}$ dry matter).

Hygroscopicity: was determined according to the methodology proposed by Cai \& Corke (2000). Approximately $2 \mathrm{~g}$ of the sample was weighed in plastic capsules, which were placed in a glass desiccator containing a saturated sodium chloride solution ( $75 \%$ UR) at $25^{\circ} \mathrm{C}$. During the adsorption process, the samples were periodically weighed until they reached hygroscopic equilibrium. Hygroscopicity was expressed as grams of moisture adsorbed per $100 \mathrm{~g}$ of dry sample $\left(\mathrm{g} .100 \mathrm{~g}^{-1}\right)$.

\section{Mechanical properties}

Tensile strength (TS) and percent elongation at break $(\% \mathrm{E})$ were determined using a QTS texture analyzer (Brookfield, Middleboro, MA, USA) according to the standard ASTMD 882 method (Davanço et al., 2007). The dehydrated product samples were cut into $100 \mathrm{~mm}$ long and $25 \mathrm{~mm}$ wide pieces. The initial gap between the grips and the test speed were set to $50 \mathrm{~mm}$ and $2 \mathrm{~mm} \cdot \mathrm{s}^{-1}$, respectively.

Tensile strength was calculated by dividing the maximum force at product rupture $\left(\mathrm{F}_{\mathrm{M}}\right)$ by the cross-sectional area $(\mathrm{A})$ (Equation 1). \%E was determined by dividing the final distance $\left(d_{f}\right)$ of the probes by the initial distance $\left(d_{i}\right)(50 \mathrm{~mm})$ multiplied by 100 (Equation 2) (Zavareze et al., 2012).

The mean thickness $(\mathrm{mm})$ required to calculate the cross-sectional area was determined using five measurements taken along the product with an Insize 3103-25 digital micrometer (Buenos Aires, Argentina) with $\pm 0.002 \mathrm{~mm}$ precision.

$$
T S=\frac{F_{M}}{A}
$$


$\% E=\frac{d_{f}}{d_{i}} x 100$

where $\mathrm{TS}=$ tensile strength $(\mathrm{MPa}) ; \mathrm{F}_{\mathrm{M}}=$ maximum force at the moment of product rupture $(\mathrm{N}) ; \mathrm{A}=$ cross-sectional area of the film $\left(\mathrm{m}^{2}\right) ; \% \mathrm{E}=$ elongation $(\%) ; \mathrm{d}_{\mathrm{f}}=$ distance at the time of rupture $(\mathrm{mm}) ; \mathrm{d}_{\mathrm{i}}=$ initial gap $(\mathrm{mm})$.

\section{Particle morphology}

Particle morphology was assessed using a LEO-1430 (LEICA, Cambridge, UK) scanning electron microscope (SEM) using $80 \mathrm{~mA}$ and $5 \mathrm{kV}$. The samples were fixed to aluminum cylinders with double-sided tape and coated with a gold layer (Bal-Tec SCD 050).

Table 1. Physicochemical composition of mammee apple pulp on wet basis.

\begin{tabular}{lc}
\hline \multicolumn{1}{c}{ Chemical composition $\left(\mathrm{g} .100 \mathrm{~g}^{-1}\right)$} & Mammee apple pulp \\
\hline Moisture & $89.53 \pm 0.13$ \\
Lipids & $0.14 \pm 0.07$ \\
Proteins & $0.31 \pm 0.09$ \\
Ash & $0.18 \pm 0.34$ \\
Carbohydrates & $9.82 \pm 0.07$ \\
Total sugars & $3.15 \pm 0.07$ \\
Reducing sugars & $3.08 \pm 0.02$ \\
Titratable acidity $\left(\mathrm{g} .100 \mathrm{~mL}^{-1}\right.$ malic acid) & $0.25 \pm 0.01$ \\
Total soluble solids $(\%$ Brix $)$ & $12.5 \pm 0.58$ \\
Water activity & $0.99 \pm 0.01$ \\
pH & $3.76 \pm 0.05$ \\
Total carotenoids $\left(\mu \mathrm{g} .100 \mathrm{~g}^{-1} \beta \text {-carotene }\right)^{* *}$ & $161.34 \pm 0.40$ \\
Antioxidant capacity $(\mu \mathrm{M} \mathrm{Trolox.g})^{* *}$ & $31.96 \pm 0.76$ \\
Color analysis & \\
$\mathrm{L}^{*}$ & $43.88 \pm 0.23$ \\
$\mathrm{a}^{*}$ & $7.31 \pm 0.09$ \\
$\mathrm{~b}^{*}$ & $29.37 \pm 0.17$ \\
$\mathrm{C}$ & $30.26 \pm 0.20$ \\
$\mathrm{~h}^{*}$ & $76.01 \pm 0.10$ \\
\hline$* *$ Dry basis.
\end{tabular}

\section{Results and discussion}

The results obtained in the analyses of mammee apple (Mammea americana L.) pulp are presented in Table 1.

The physicochemical composition of the mammee apple pulp presented similar values to those observed by Braga et al. (2010) and Péroumal et al. (2017). Based on its pH, mammee apple is classified as an acidic fruit (Chisté \& Cohen, 2011).

The total RW drying time for mammee apple was $50 \mathrm{~min}$, generating a dehydrated product with final moisture content of $8.32 \%$ (dry basis). This is a short drying time compared to those found for traditional drying processes such as freeze-drying, drum-drying, and pulsed vacuum drying (Baeghbali et al., 2016; Link et al., 2017).

Usually, RW rapidly decreases the final moisture content with minimum nutrient loss, since it uses temperatures lower than $100^{\circ} \mathrm{C}$ (Costa et al., 2019).

The results for the dry product are presented in Table 2. The drying process retained $64 \%$ of the total carotenoid concentration of mammee apple, qualifying the dehydrated product as a source of provitamin A.

Table 2. Color analysis, technological, and mechanical properties of dehydrated product ${ }^{\star}$.

\begin{tabular}{lc}
\hline \multicolumn{1}{c}{ Color analysis } & Dehydrated product \\
\hline $\mathrm{L}^{*}$ & $39.85 \pm 0.59$ \\
$\mathrm{a}^{*}$ & $0.69 \pm 0.13$ \\
$\mathrm{~b}^{*}$ & $25.15 \pm 0.24$ \\
$\mathrm{C}$ & $25.16 \pm 0.24$ \\
$\mathrm{~h}^{*}$ & $88.42 \pm 0.30$ \\
Technological Properties & \\
Water solubility index (WSI) (\%) & $32.73 \pm 0.67$ \\
Water absorption index (WAI) (g.g $\left.\mathrm{g}^{-1}\right)$ & $7.60 \pm 0.13$ \\
Hygroscopicity (H $\left.\mathrm{H}_{2} \mathrm{O} 100 \mathrm{~g}^{-1}\right)$ & $21.46 \pm 0.59$ \\
Mechanical Properties & \\
Tensile strength (TS) MPa & $1.15 \pm 0.34$ \\
Percent elongation (\%E) & $13.93 \pm 0.51$ \\
\hline
\end{tabular}
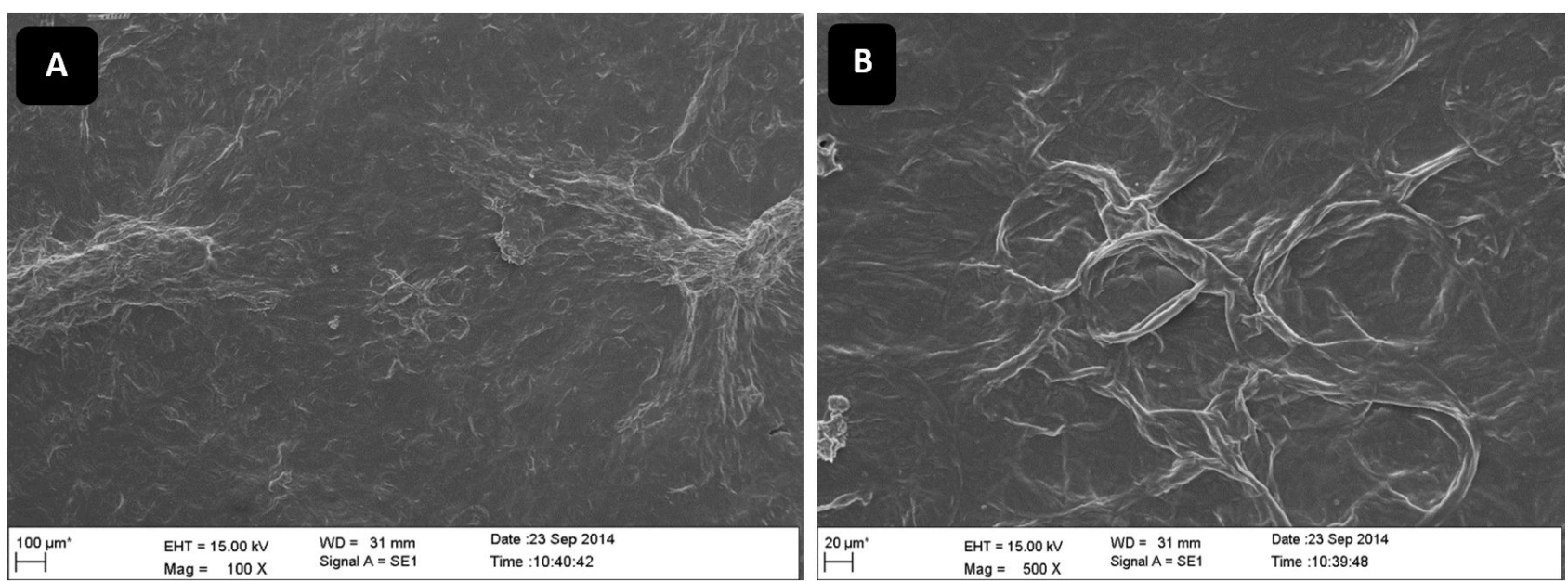

Figure 1. Microstructure of the product obtained at 100 (A) and $500 \mathrm{X}$ (B) magnification. 
The product's hygroscopicity was lower than that observed for mango pulp dried by RW (Caparino et al., 2012). This may be related to differences in composition between the two raw materials, since hygroscopicity is related to the presence of amorphous compounds, such as sugars, in matrices. Low hygroscopicity guarantees chemical and microbiological stability during storage (Tontul et al., 2018).

TS was lower in our product than in films obtained from fruit residues (Farias et al., 2012) and higher than reported for edible starch films with added safflower (Campo et al., 2016). This low TS was explained by conformational changes in the molecular structure of the dehydrated product, formed by the plastifying effect of water used in the formulation (Cuq et al., 2011).

\subsection{Particle morphology}

Micrographs of the dehydrated product in film format, magnified by 100 (A) and 500 (B) times, are presented in Figure 1. It presented a regular shape with a regular shape with a smooth surface, and thin elongated structures related to food fibers present in the raw material.

\section{Conclusion}

The present results indicate that RW drying is a viable and promising alternative to current drying methods, resulting in the retainment of bioactive compounds, and generating a dry product that can be considered a source of provitamin A.

The dehydrated product presented good tensile strength and percent elongation at break, and a high water solubility index, favoring its application as an edible film. In addition, it presented film characteristics without the need for additives or auxiliary addition.

\section{Acknowledgements}

The authors thank PROPESP/UFPA (Provost's Office for Research and Graduate Studies of the Federal University of Pará), $\mathrm{CNPq}$ (National Research and Development Council, processes 308021/2015-0 and 477013/2013-9), and CAPES (Coordination for the Improvement of Higher Education Personnel).

\section{References}

Abonyi, B. I., Feng, H., Tang, J., Edwards, C. G., Chew, B. P., Mattinson, D. S., \& Fellman, J. K. (2002). Quality retention in strawberry and carrot purees dried with Refractance Window system. Journal of Food Science, 67(3), 1051-1056. http://dx.doi.org/10.1111/j.1365-2621.2002. tb09452.x.

Anderson, R. A., Conway, V. F. P., \& Griffin, E. L. (1969). Gelatiniozation of corn grits byroll-and extrusion-cooking. Cereal Science Today, 14(1), 4-7.

Association of Official Analytical Chemists - AOAC. (1997). Official methods of analysis of the Association of Official Analytical Chemists (16th ed.). Gaithersburg: AOAC.

Baeghbali, V., Niakousari, M., \& Farahnaky, A. (2016). Refractance Window drying of pomegranate juice: quality retention and energy efficiency. Lebensmittel-Wissenschaft + Technologie, 66, 34-40. http:// dx.doi.org/10.1016/j.lwt.2015.10.017.
Biazotto, K. R., Mesquita, L. M. S., Neves, B. V., Braga, A. R. C., Tangerina, M. M. P., Vilegas, W., Mercadante, A. Z., \& Rosso, V. V. (2019). Brazilian biodiversity fruits: discovering bioactive compounds from underexplored sources. Journal of Agricultural and Food Chemistry, 67(7), 1860-1876. http://dx.doi.org/10.1021/ acs.jafc.8b05815. PMid:30707576.

Braga, A. C. C., Silva, A. E., Pelais, A. C. A., Bichara, C. M. G., \& Pompeu, D. R. (2010). Atividade antioxidante e quantificação de compostos bioativos dos frutos de abricó (Mammea americana). Alimentos e Nutrição, 21(1), 31-36. Retrieved from http://serv-bib.fcfar.unesp. br/seer/index.php/alimentos/article/viewFile/1386/908

Brasil, Ministério da Saúde, Agência Nacional de Vigilância Sanitária - ANVISA. (2003, 26 de dezembro). Regulamento técnico sobre rotulagem nutricional de alimentos embalados (Resolução RDC $\mathrm{n}^{\circ}$ 360, de 23 de dezembro de 2003). Diário Oficial [da] República Federativa do Brasil.

Cai, Y. Z., \& Corke, H. (2000). Production and properties of spray-dried Amaranthus betacyan in pingments. Journal of Food Science, 65(7), 1248-1252. http://dx.doi.org/10.1111/j.1365-2621.2000.tb10273.x.

Campo, C., Costa, T. M. H., Rios, A. O., \& Flôres, S. H. (2016). Effect of incorporation of nutraceutical capsule waste of safflower oil in the mechanical characteristics of corn starch films. Food Science and Technology, 36(Suppl. 1), 33-36. http://dx.doi.org/10.1590/1678457x.0049.

Canuto, G. A. B., Xavier, A. A. O., Neves, L. C., \& Benassi, M. T. (2010). Caracterização físico-química de polpas de frutos da Amazônia e sua correlação com a atividade anti-radical livre. Revista Brasileira de Fruticultura, 32(4), 1196-1205. http://dx.doi.org/10.1590/S010029452010005000122.

Caparino, O. A., Tang, J., Nindo, C. I., Sablani, S. S., Powers, J. R., \& Fellman, J. K. (2012). Effect of drying methods on the physical properties and microstructures of mango (Philippine 'Carabao' var.) powder. Journal of Food Engineering, 111(1), 135-148. http://dx.doi. org/10.1016/j.jfoodeng.2012.01.010.

Castoldi, M., Zotarelli, M. F., Durigon, A., Carciofi, B. A. M., \& Laurindo, J. B. (2015). Production of tomato powder by Refractance Window drying. Drying Technology, 33(12), 1463-1473. http://dx.doi.org/10 .1080/07373937.2014.989327.

Chisté, R. C., \& Cohen, K. O. (2011). Influência da fermentação na qualidade da farinha de mandioca do grupo d'água. Revista Acta Amazônica., 41(2), 279-284. http://dx.doi.org/10.1590/S004459672011000200013

Costa, R. D. S., Rodrigues, A. M. C., Laurindo, J. B., \& Silva, L. H. M. (2019). Development of dehydrated products from peach palm-tucupi blends with edible film characteristics using refractive window. Journal of Food Science and Technology, 56(2), 560-570. http://dx.doi. org/10.1007/s13197-018-3454-x. PMid:30906013.

Cuq, B., Rondet, E., \& Abecassis, J. (2011). Food powders engineering, between knowhow and science: Constraints, stakes and opportunities. Powder Technology, 208(2), 244-251. http://dx.doi.org/10.1016/j. powtec.2010.08.012.

Davanço, T., Tanada-Palmu, P., \& Grosso, C. (2007). Filmes compostos de gelatina, triacetina, ácido esteárico ou capróico: efeito do $\mathrm{pH}$ e da adição de surfactantes sobre a funcionalidade dos filmes. Revista Ciência e Tecnologia de Alimentos, 27(2), 408-416. http://dx.doi. org/10.1590/S0101-20612007000200034.

Farias, M. G., Fakhouri, F. M., Carvalho, C. W. P., \& Ascheri, J. P. R. (2012). Caracterização físico-química de filmes comestíveis de amido adicionado de acerola (Malphigiaemarginata D.C.). Química Nova, 35(3), 546-552. http://dx.doi.org/10.1590/S0100-40422012000300020.

Hunterlab. (2008). CIE L* a $\mathrm{b}^{*}$ color scale. Applications Note, 8(7), 1-4. 
Karam, M. C., Petit, J., Zimmer, D., Djantou, E. B., \& Scher, J. (2016). Effects of drying and grinding in production of fruit and vegetable powders: a review. Journal of Food Engineering, 188, 32-49. http:// dx.doi.org/10.1016/j.jfoodeng.2016.05.001.

Lane, J. H., \& Eynon, L. (1984). Determination of reducing sugars by Fehling's solution with methylene blue indicator. London: Normam Rodge.

Link, J. V., Tribuzi, G., \& Laurindo, J. B. (2017). Improving quality of dried fruits: a comparison between conductive multi-flash and traditional drying methods. Lebensmittel-Wissenschaft + Technologie, 84, 717-725. http://dx.doi.org/10.1016/j.lwt.2017.06.045.

Minjares-Fuentes, R., Rodríguez-González, V. M., González-Laredo, R. F., Eim, V., González-Centeno, M. R., \& Femenia, A. (2017). Effect of different drying procedures on the bioactive polysaccharideacemannan from Aloe vera (Aloe barbadensis Miller). Carbohydrate Polymers, 168, 327-336. http://dx.doi.org/10.1016/j.carbpol.2017.03.087. PMid:28457457.

Nindo, C. I., \& Tang, J. (2007). Refractance Window dehydration technology: a novel contact drying method. Drying Technology, 25(1), 37-48. http://dx.doi.org/10.1080/07373930601152673.

Nindo, C. I., Feng, H., Shen, G. Q., Tang, J., \& Kang, D. H. (2003a). Energy utilization and microbial reduction in a new film drying system. Journal of Food Processing and Preservation, 27(2), 117-136. http://dx.doi.org/10.1111/j.1745-4549.2003.tb00506.x.

Nindo, C. I., Sun, T., Wang, S. W., Tang, J., \& Powers, J. R. (2003b). Evaluation of drying technologies for retention of physical quality andantioxid ants in asparagus (Asparagus officinalis, L.). Swiss Society of Food Science and Technology, 36, 507-516.

Nindo, C. I., Tang, J., Powers, J. R. E., \& Bolland, K. (2004). Energy consumption during Refractance Window evaporation of selected berry juices. International Journal of Energy Research, 28(12), 10891100. http://dx.doi.org/10.1002/er.1017.

Ochoa-Martínez, C. I., Quintero, P. T., Ayala, A. A., \& Ortiz, M. J. (2012). Drying characteristics of mango slices using the Refractance Window $^{\mathrm{ma}}$ technique. Journal of Food Engineering, 109(1), 69-75. http://dx.doi.org/10.1016/j.jfoodeng.2011.09.032.

Oliveira, K. D. C., Silva, S. S., Loss, R. A., \& Guedes, S. F. (2019). Análise sensorial e físico-química de geleia de achachairu (Garcinia humillis (Vahl) C. D. Adam). Segurança Alimentar e Nutricional, 26, e019007. http://dx.doi.org/10.20396/san.v26i0.8653566.
Pavan, M. A., Schmidt, S. J., \& Feng, H. (2012). Water sorption behavior and termal analysis of freeze-dried, refractance window-dried and hot-air dried acai (Euterpe oleracea Martius) juice. Food Science and Technology, 48, 75-81.

Péroumal, A., Adenet, S., Rochefort, K., Fahrasmane, L., \& Aurore, G. (2017). Variability of traits and bioactive compounds in the fruit and pulp of sixmamey apple (Mammea americana L.) accessions. Food Chemistry, 234(1), 269-275. http://dx.doi.org/10.1016/j. foodchem.2017.04.145. PMid:28551236.

Putranto, A., Chen, X. D., \& Webley, P. A. (2010). Infrared and convective drying of thin layer of polyvinyl alcohol (PVA)/glycerol/water mixture, the reaction engineering approach (REA). Chemical Engineering and Processing, 49(4), 348-357. http://dx.doi.org/10.1016/j.cep.2010.03.010.

Quinteros, A., Terleira, E., Ramírez, J., García, P., Garay, R., Castro, P., \& Chumacero, J. (2018). Osmotic dehydration in native fruits (Mammea americana L. and Mammea americana L.) and vegetables (Capsicum annuum L.) of the Amazon region. Agro Science, 8(2), 95-101. http://dx.doi.org/10.17268/agroind.sci.2018.02.03.

Rodrigues, A. M. C., Bezerra, C. V., Silva, I. Q., \& Silva, L. H. M. (2016). Propriedades Reológicas do Suco de Buriti (Mauritia flexuosa). Revista Brasileira de Fruticultura, 38(1), 176-186. http://dx.doi. org/10.1590/0100-2945-290/14.

Rodrigues-Amaya, D. B. (2001). A guide to carotenoids análysis in food. Washington: OMNI Research, ILSI Human Nutritional Institute.

Rufino, M. S. M., Alves, R. E., Brito, E. S., Moraes, S. M., Sampaio, C. G., Perez-Jimenez, J., \& Saura-Calixto, F. D. (2007). Metodologia cientifica: determinação da atividade antioxidante total em frutas pela captura do radical livre ABTS (pp. 4, Comunicado Técnico, No. 127). Fortaleza: Embrapa Agroindustria Tropical.

Tontul, I., Kasimoglu, Z., Asik, S., Atbakan, T., \& Topuz, A. (2018). Functional properties of chickpea protein isolates dried by refractance window drying. International Journal of Biological Macromolecules, 109, 1253-1259. http://dx.doi.org/10.1016/j.ijbiomac.2017.11.135. PMid:29175165.

Zavareze, E. A., Halal, S. L. M., Telles, A. C., \& Prentice-Hernández, C. (2012). Filmes biodegradáveis à base de proteínas miofibrilares de pescado. Brazilian Journal of Food Technology, 15(spe), 53-57. http://dx.doi.org/10.1590/S1981-67232012005000038.

Zotarelli, M. F., Carciofi, B. A. M., \& Laurindo, J. B. (2015). Effect of process variables on the drying rate of mango pulp by Refractance Window. Food Research International, 69, 410-417. http://dx.doi. org/10.1016/j.foodres.2015.01.013. 